\title{
The Principles Of Liability On Telemedicine Practices
}

\author{
Arman Anwar ${ }^{1}$ \\ ${ }^{1}$ Faculty of Law, Pattimura University \\ Jln. Ir. M. Putuhena Kampus Poka, Ambon, 97233, Indonesia \\ Tel/Fax: +62-911-3825204 E-mail: Arman_1170@yahoo.com.au
}

\begin{abstract}
This research was aimed at analyzing and finding the principle of liability in telemedicine medical practice proportionally.This research is a legal research with the approach of statute approach, conceptual approach and comparative approach, as well as the approach to the case approach. According to Article 24 paragraph (1) of the 1945 Constitution and Article 5 (1) of Act No. 48 of 2009 on Judicial Authority, determine that the judge shall explore, and understand the legal values and sense of justice in society. Thus Article 1367 paragraph (3) BW and Article 46 of Act No. 44 of 2009 on Hospitals in the application must be in the context of the intended. The principle of liability risk in medical practice telemedicine in proportion refers to professional liability among medical practitioners telemedicine. The theoretical legitimacy is based on professional relationships in the delegation of medical action based on the code of ethics, professional standards, and service standards, and standard operating procedures. Consequences on liability does not necessarily have to be based on errors primary physician (primary care physician / PCP) or primary nurse as subordinate as mean vicarious liability doctrine. Nomenclature "proportional" in a significant liability risk as the distribution of rights and obligations of professionals in proportion to each party's fault based on the values of equality (equitability), feasibility and appropriateness (fair and reasionableness). Accountability based on the viewpoint of interactive justice according to the values of professional skill, prudence or accuracy, responsibility, and colleague and the desire to do good for the sake of healing patients (doing good).
\end{abstract}

Keywords: Liability; Medical Practice; Telemedicine

\section{INTRODUCTION}

Technology plays an important role in human life, almost the entire nation in any corner of the world, use of technology in their lives. Between one nation with another nation can be connected in a pattern of life also thanks to the help of technology. The acceleration in various aspects of life has changed that had become a unified life. The implication of 
this is the life that united called globalization. ${ }^{1}$ Wallerstein said that globalization is a process of establishing a capitalist world is dragging the nations in an effort to attempt to develop the country from various facets of life by utilizing technology. So that today every country are challenged to master the development of science and technology. ${ }^{2}$ The mastery of science and technology (science and technology) in all sectors increasingly broad and globalization has helped bring the influence of increasingly complex in all fields, not least also in the field of science and health technologies such as telemedicine. Advances in technology telemedicine health can not be separated from the domino effect of the rapid development of information technology. Schumpeter asserted that the influence of the information technology industry has come to the health sector and others. This is because the information technology industry has character and a different market with contemporary economics. It has been predicted that the innovation of science and information technology to

\footnotetext{
${ }^{1}$ Satjipto Rahardjo. (1997). "Pembangunan Hukum Indonesia dalam Konteks Situasi Global”, Jurnal Perspektif, 2 (2): 2.

${ }^{2}$ Ibid, pg.1
}

build a new economy (new economy) that will drive economic growth ${ }^{3}$.

In line with these opinions Danrivanto Budhijanto, said that along with the increase in social and economic activities make a constellation of society the world has entered an informationoriented society. Information systems technology has been used in many sectors of life, ranging from trade / business (electronic commerce or e-commerce), education (electronic education), health (telemedicine), telekarya, transport, industry, tourism, the environment to the entertainment sector ${ }^{4}$ World Health Association (WHO) defines telemedicine as:

"The delivery of health care services, where distance is a critical factor, by all health care professionals using information and communication technologies for the exchange of valid information for diagnosis, treatment and prevention of disease and injuries, research and evaluation, and for the continuing education of health care providers, all in the interests of advancing the health of individuals and their communities". 5

\footnotetext{
${ }^{3}$ Arief B. Witarto. (2005). Kebebasan dan Etika Ilmu Pengetahuan, Harian Bisnis Indonesia, (21 Oktober 2005).

4 Danrivanto Budhijanto. (2010). Hukum Telekomunikasi Penyiaran dan Teknologi Informasi Regulasi dan Konvergen. Bandung: Refika Aditama, pg. 1

${ }^{5}$ Craig J, Patterson V. (2005). "Introduction to the Practice of Telemedicine". Journal Telemedicine and Telecare, 11(1): $3-9$.
} 
Referring to the definition of the WHO, the telemedicine is a form of the provision of health care services by health professionals, using information and communication technologies through the exchange of valid information to provide diagnostic, preventive treatment of disease and injury, as well as for the supply of education and training for the improvement of the quality of providers health services as well as for research and evaluation, where distance is no longer a constraint to implement it all.

Apart from the expectation that telemedicine promises greater convenience and opportunities that could be one solution in addressing the issue of health, but also realize that telemedicine brings the potential legal issues in the practice of medicine. According Gorea R.K, that there are many legal implications related to medico legal telemedicine such as registration, licensing, insurance, quality of privacy, and confidentiality issues, as well as other risks associated with electronic health care communication. Another important aspect is the doctor-patient relationship, the standard of care and informed consen. ${ }^{6}$

6 R. K. Gorea. (2005). "Legal Aspects of Telemedicine: Telemedical Jurisprudence". Journal of Punjab Academy of Forensic Medicine \& Toxicology, 5 : 3
In the view of David Storey D, that specifically in the United States, there are at least five legal issues that require settings before launching a telemedicine program. The fifth problem is the law of the state licensure and credentialing of physicians, physician malpractice liability in Regulation FDA (US Food and Administration) of the State, the security of patient health information data, as well as insurance issues. $^{7}$

Based on the description above background, medical practice telemedicine has the potential to cause a variety of legal issues (medico legal). Accumulation of these problems could have implications jurisdiction over aspects of accountability in medical practice telemedicine. It is becoming very urgent and important to be studied.

\section{METHODS}

The type and specification of the study refers to the opinion of Peter Mahmud Marzuki that legal research is a process of finding the rule of law, principles of law, and the legal doctrines in order to address the legal issues at hand. This is consistent with the prescriptive character of the

\footnotetext{
${ }^{7}$ David Storey D. The Closer View About Law Issues In Telemedicine. http://www.hhnmag.com/hhnmag/jsp/articledisplay.jsp? dcrpath $=$ HHNMO, access on 12 July 2012
} 
science of law. ${ }^{8}$ Based on these ideas, this study represents an effort to find answers to legal issues in medical practice telemedicine. Therefore, the use of normative legal research and research doctrinal.

Approach to problems that used in this study is the approach of legislation (statute approach), the conceptual approach (conceptual approach), and the comparative approach (comparative approach). As well as case-based approach (case approach).

Legal materials used in the form of primary and secondary legal materials. Procedures for the collection and analysis of legal materials do with measures abbreviated to "IRAC" such as choosing the issue (issues), determine the rules of relevant laws (rule of law), and then analyze the facts from a legal perspective (analyzing the facts), ultimately resulted in the preparation of a conclusion (conclusion). Step Such a technique called "brainstorming" which is part of the planning step up research. ${ }^{9}$

\section{ANALYSIS AND DISSCUSSION Characteristics Of Telemedicine In Medical Practice}

\footnotetext{
${ }^{8}$ Peter Mahmud Marzuki. (2010). Penelitian Hukum, Edisi 6. Jakarta: Kencana Pernadia Media Grup. pg. 35

${ }^{9}$ Terry Hutchinson, (2002). Researching and Writing in Law. Sydney: Law book. Co. Pyrmont-NSW. pg. 32
}

\section{"International"Characteristics}

\section{Telemedicine Medical Practice}

Model of trade in services is called the cross-border mode of supply is the way cross-border provision of services in which service providers and service recipients are in their respective countries, but these services go beyond / past state borders ${ }^{10}$. Telemedicine has led to the diffusion of medical technology that have an impact on the development of technology and the needs of the community access to health services that are practical and efficient, it gives birth to the concept of e-Health in response to these demands. Given the function of WHO as an international institution responsible for the areas of health, the WHO has issued resolution number 200558.28 on e-Health. In that resolution, the WHO encourages countries to:

1) Develop a long-term strategic plan to develop e-health services in various areas of health is good for health administration, legal and regulatory frameworks, infrastructure as well as public and private partnership mechanism.

2) Developing ICT infrastructure for $e$ health.

\footnotetext{
${ }^{10}$ Peter van Bossche dkk. (2010). Pengantar Hukum WTO (Word Trade Organization). Jakarta: Yayasan Obor Indonesia. pg. 14
} 
3) Establish collaboration with the private sector and profit agency to support e-health.

4) Develop e-health to reach the public, especially vulnerable to health problems (vulnerable) and in accordance with their needs.

5) Mobilize cooperation across sectors in adopting the norms and standards of e-health, evaluation, the principles of cost-effectiveness in e-health to ensure the quality, ethics and security by promoting confidentiality, privacy, equity and equality.

6) Develop a network of centers of excellence and e-health.

7) Develop a model public health information systems for surveillance, and emergency response.

The formulation of the WHO resolution as mentioned above it can be seen that the meaning of state responsibility that must be implemented by each government enormous nation in health development efforts. The government is responsible to plan, organize, organize, develop, and oversee the implementation of e-health by preparing all the necessary good health administration, legal frameworks and regulations, infrastructure and WHO mechanisms resolution referred to require the government to develop e-Health give expediency for marginal community, especially those prone to health problems (vulnerable) and in accordance with their needs.

Associated with the liberalization of the field of health services in ASEAN, the ASEAN Framework Agreement stipulated in the Agreement on services (AFAS). One of the three terms of the agreement is to facilitate the free flow of services through mutual recognition arrangements of competence (mutual recognition arrangements / MRA). And while there is the possibility of foreign doctors can practice cross-country ASEAN is still under discussion and is expected to be ASEAN has not reached agreement on that in the near future ${ }^{11}$. While in the European Union, it was arranged that the regulatory authorities must ensure that the regulatory authority has certified the facilities and working procedures or through an accredited system performed by a qualified auditor $^{12}$. Elias Mossialos, Sarah Thomson and Annemarie Ter Linden said that to facilitate the certification services across

\footnotetext{
${ }^{11}$ Agus Purwadianto. "Praktisi Medis Siap Bersaing dalam Masyarakat ASEAN. Majalah Masyarakat ASEAN, Media Publikasi Direktorat Kerja Sama ASEAN Kementrian Luar Negeri, Edisi 6, December 2014. pg. 65

${ }^{12}$ Elias Mossialos, Sarah Thomson and Annemarie Ter Linden. (2004). "Information Technology Law and Health Systems in the European Union". International Journal of Technology Assessment in Health Care, 20 (4): 498-508.
} 
national borders must be made through the mutual recognition of certification services from their respective countries as long as through the requirements of the Directive and has been accredited by any agency recognized by the European Union, or are recognized by agreements bilateral between the EU and third countries or international organizations ${ }^{13}$.

\section{Telemedicine Medical Practice in}

\section{Indonesia}

Their tendency of some patients in Indonesia to use technology to telemedicine cross country, causing some hospital like Gading Pluit Hospital, Sahid Hospital and JEC Hospital, as well as at the RSCM, has apply telemedicine are implemented in the form of seminars and surgery (surgery online). ${ }^{14}$ Husada Utama Surabaya Hospital 15 , and Regional General Hospital dr. Soetomo did in the form of teleradiology ${ }^{16}$, and RSUPN Dr. Cipto Mangunkusumo, and Hospital Cardiovascular Harapan Kita Jakarta, officially appointed by the Ministry of

\footnotetext{
${ }^{13} \mathrm{Ibid}$

14 Telemedicine apakah dapat diterapkan di Indonesia, be in http://khalidmustafa.info access on 12 February 2011

${ }^{15}$ Interview with Anggraini dan M. Puguh Arifianto, Radiologists dan Operator/Provider Sistem Elektronik R.S. Husada Utama, Thursday, 9 February 2012, time on 15.00-16.00 PM WIB

16 Pemerintah Provinsi Jawa Timur. Rencana Strategis (Renstra) Rumah Sakit Dr. Soetomo Tahun 2009-2014. pg. 58
}

Health to conduct medical practice in the form of teleradiology and telemedicine telecardiologi. ${ }^{17}$

Indonesia's commitment to improving the health of the world access to knowledge and telemedicine services, can be said to be too late in the preparation of regulatory rules about telemedicine. In contrast to Malaysia, India or the United States. Indonesia is merely set general telematics through Act No. 11 of 2008 on Information and Electronic Transactions. While specific regulations on new telemedicine limited to the Director General of Health Efforts by the Ministry of Health of the Republic of Indonesia Number: HK.02.03/V/0209/2013 Date January 31, 2013 on the Implementation of the Pilot Project of Telemedicine and Health Care Facilities Designation Teleradiology and Telemedicine Sector Telecardiologi.

\section{Legal Relationships In Telemedicine Medical Practice \\ Setting Telemedicine Medical Practice in Legal Medicine}

According to a decree of the Director General of Health Efforts Ministry of Health of the Republic of Indonesia

\footnotetext{
${ }^{17}$ Interview with Hisal Saragih, The Head of Law and Organization Division - RSUPN Dr. Cipto Mangunkusomo, Tuesday, 29 October 2013, time on 09.00-10.00 AM WIB
} 
Number: HK.02.03 / V / 0209/2013 Date January 31, 2013 on the Implementation of the Pilot Project of Telemedicine and Health Care Facilities Designation teleradiology and Telemedicine Sector Telecardiologi. Then set two (2) health care facilities namely to the field of telemedicine, health care facilities, namely is RSUPN dr. Cipto Mangunkusumo and for field telekardiologi, health care facility namely is Harapan Kita Cardiovascular Hospital Jakarta. While healthy care facility of teaching consists of 18 (eighteen) health care facility form field hospital, Main Clinic Ministry of Health, Ambulance and health centers, and hospitals are scattered in some disadvantaged areas, border and island (DABI).

Studying the decree on the forms of medical practice were piloted telemedicine is in the form of a store and forward (asynchronous telemedicine). Hospitals that acts as a special location, namely where the non-clinical medical specialist hospitals are designated. While hospitals or health care facilities of teaching is a hospital or care facility that acts as the site of a presentation that is where clinical doctors and patients are located. He used the term and of teaching can be interpreted that this cooperation contained in the purpose of providing protection, security, and development of the support of teaching. Therefore, their implied meaning to the responsibility of support of teaching.

This decree nature just as the letter of appointment from the Ministry of Health of the Republic of Indonesia to the hospital and healthy care facilities which is considered to have systems and telemedicine technology devices and the availability of good internet network. Cooperation set out in the decree covers only the provision of consultancy services expertise and radiology and emergency cardiovascular (mainly acute coronary syndromes). For that set the technical delivery mechanism and the electronic transmission of radiographic images and all modalities of radiology and ECG recordings called teleradiology and telecardiologi.

Given the decree is merely a reference to the health care facility then certainly more emphasis on the technical aspects of setting his ministry rather than the regulation of the legal aspects of the relationship. Therefore, it is in accordance with the dictum of the seven decree mentions that setting the legal relationship of the parties in the implementation of the Pilot Project of Telemedicine will be realized further in the cooperation 
agreement of its own between health care facility support and of teaching to be known by General Director of Health Services Ministry of Health , but until now the cooperation agreement is still in the drafting process (drafting).

\section{Legal Relationship of Parties in the} Medical Practice of Telemedicine Telemedicine Medical Practice Form In Real Time (Synchronous Telemedicine)

Legal relationship in medical practice telemedicine can be distinguished based on the timing, a time when information is transmitted or interactions between individuals involved in medical practice telemedicine is happening. So that the medical practice of telemedicine can be divided into two types, namely real time (synchronous telemedicine) and store-andforward (asynchronous telemedicine) ${ }^{18}$. For the first type is generally in practice the form of teleassistance, telemonitoring and teleconsultation.

Before providing health services to patients, the medical practice telemedicine providers as service providers, will ask the patient's consent for the use of such services. Letter of consent (informed consent) that was created in the form of raw agreement. Some of the provisions

\footnotetext{
18 Telemedicine and e-Health Development, in www.telemed.org.ua, access on 23 August 2013
}

stipulated in the informed consent is that the patient's identity, the name of the provider, the information that the patient's physician or/his representative has recommended the use of telemedicine consultations for the patient's medical condition. The explanation given to the patient about all the possibilities that could happen. Patients have also been notified and given a written description of the benefits and risks. ${ }^{19}$ The next step is a person appointed at the site presentation will present patient data and medical. Patients will be linked on line to use the video facility consulting (simultaneously) live, guided by the primary nurse, or doctor PCP (primary care physician) to consult with a specialist at the same time so that the patient's medical condition can be discussed together with specialists in medical practice telemedicine question. Once the consultation is complete telemedicine, telemedicine specialists it sends a recommendation to the referring physician via the website or by specialist presentations directly.

\footnotetext{
${ }_{19}$ Authorization and Consent to Participate in a Telemedicine Consultation, Anthem Blue Cross Partnership Plan. Independent licensees of the Blue Cross Association. () ANTHEM is a registered trademark. ( The Blue Cross name and symbol are registered marks of the Blue Cross Association. 0108 CAW2085 02/23/08
} 
Telemedicine Medical Practice Form in Store and Forward (Asynchronous Telemedicine)

The thing that distinguishes this form with real time (synchronous telemedicine) is the use of software by a clinical physician at the presentation site to store and encrypt images and medical data of patients. This data is then secured and transmitted electronically to a specialist nonclinical at specific locations to be consulted, reviewed and evaluated offline. Hence, telemedicine type is non-interactive because it does not require the presence of both parties (patients, presenters and specialists) in the same time. Dermatologists, radiologists, and patalog are specialists who typically use asynchronous telemedicine.

The stages of implementation in medical practice telemedicine this type is to collect medical data is required (for example, the data of clinical information and medical records of patients) by filling out the form demographer and include information referring site, the name of the doctor PCP, and patient information including medical history as well as specific questions other questions to ask to specialists. Further forward to a special treatment providers using e-mail encrypted by the site to a specialist desired presentation. After medical imagery interpreted by subsequent specialist interpretation of medical images will be transmitted/transferred back by specialist accompanied by an explanation to the PCP doctor.

\section{Liability Risk As Proportional In Practice Of Medical Telemedicine Liability Risks in Medical Legal Aspects} In essence, the principle of accountability based on respect for patients' rights, namely the right to advocacy and protection of medical efforts to resolve disputes as to be able to get compensation or compensation due to physician malpractice. The settings in the health law on the rights of patients to doctor's demand a liability stipulated in legislation, namely Law No. 36 Year 2009 on Health, Law Number 29 Year 2004 on Medical Practice and Law Number 44 Year 2009 About Hospital. As well as Law No. 36 Year 2014 About Health Workers.

Article 58 Paragraph (1) of Law Number 36 Year 2009 on Health states that everyone is entitled to claim damages against a person's health personnel, and / or the provider to incur losses due to errors or omissions in health care it receives. In terms of harm done by the Hospital or losses incurred on omissions by health workers then there are corporate liability based on Articles 32 and 46 of Law No. 44 
Year 2009 About Hospital. Article 32 point q. Mention that, every patient has the right to sue and / or require hospital when the hospital suspected of providing services that do not conform with the standards of either civil or criminal. Whereas Article 46 determines that the Hospital is legally responsible for all losses incurred on omissions by medical personnel at the hospital. Therefore, the physician who made the mistake personally or Hospital malpractice liability risk burdened to pay compensation to patients who are dissatisfied. In the case of devolution of medical action of medical personnel for health workers then in accordance with Article 65 paragraph (3) point c of Law number 36 of 2014 concerning health worker noted that the giver devolution remains responsible for the actions assigned throughout the implementation of the action in accordance with the delegation that it provides.

J.H. Niuwenhuis, divide liability on three (3) categories, namely ${ }^{20}$ : liability based on fault (schuldaansprakelijkheid), liability with the burden of proof (schuldaansprakelij- kheid meth dry om van bewijlast), and liability risk (risico aanspraklijkheid) which is based on Article BW 1367 and Article 1369 BW

\footnotetext{
${ }^{20}$ Djasadin Saragih. (1985). Pokok-Pokok Hukum
} Perikatan. Surabaya: Airlangga University, pg. 135
Furthermore J.H. Niuwenhuis, explaining that the liability risk in particular in Article 1367 paragraph (3) B.W determines that the employer is accountable to the losses caused by subordinates who carried out within the scope of their duties. Liability risk should be based on ${ }^{21}$ :

1) The existence of a relationship subordinates and superiors. Which specify here is the authority to give orders (instructions) to the other. This authority can arise from labor agreement, but also of public law (the relationship of rulers and civil servants).

2) Accountability depends on the circumstances that unlawful acts were done in the execution of duties by subordinates. Restrictions specified to require the court there should be a relationship between illegal and duties of a subordinate. Employers also remains responsible accountable for unlawful acts by his subordinates when performing their duties despite the fact that the employer has strongly prohibits acts concerned or though the act was outside office hours.

3) For liability Article 1367 paragraph (3) required by their unlawful and error on the part of subordinates.

4) Accountability does not depend on any violation of norms or fault by the employer. The aggrieved party holding on to enough evidence of unlawful acts by his subordinates, the superior-subordinate relationship, and the fact that the subordinate tasks create an opportunity to commit unlawful acts.

\footnotetext{
${ }^{21}$ Ibid, pg. 118
} 
Case swapped baby can be one example of liability risks specifically related to Article 1367 paragraph (3) BW. The case started to confuse the two baby girls in 1994. The occasion was the maternity clinic in the Riviera, Canes, France. At that time, Sophie gave birth to a baby girl, a baby was named Manon. Shortly after birth, Manon was detected suffering from jaundice, doctors decided Manon treated in incubator and because of the limitations incubator then Manon united by nurses with more female babies born simultaneously that day. Here is a small Manon switched with another baby. The nurse on duty when it accidentally swapping two babies. Sophie and other baby's mother is already feeling the strangeness when receiving their child after irradiation incubator. The length of their baby's hair is different. But the nurse insisted that there are no errors. The strangeness and anxiety burst into his family ten years later. Sophie husband felt that Manon has no resemblance at all with both parents. Finally they do a DNA test. The result leaves them shocked. Manon did not have DNA in common with them. The case was brought to court with a demand for compensation of Rp 27 billion. Finally, the court decided that the nurse was negligent, and commit unlawful acts to exchange the two babies. Negligence nurses reduced to clinical errors. Therefore, clinical convicted and obliged to pay damages as compensation amounted to EUR 1.88 million (equivalent to 27 billion rupiah). ${ }^{22}$

If Article 1367 paragraph (3) is constructed in the telemedicine medical practice medical practice telemedicine is a medical practice that is carried out through a combination of cooperation between specialists by primary care physicians (primary care physician/PCP). The specialist provides direction and delegated medical acts to the primary physician (primary care physician/PCP) for the next primary physician for the referral and transfer of actions that perform a medical procedure to the patient. This working relationship spawned a superior and a subordinate, which had previously been regulated in an agreement or contract. In theory, the working relationship between superiors and subordinates or between the principal with the agent causing the legal relationships that entail the liability for damages, which will be accountable is the boss (the doctrine of vicarious liability). I.e. legal fiction action servant (servant) is the act of the host (master). So that if this doctrine applied to accountability in

${ }^{22}$ Bayi Tertukar Ganti Rugi Rp 27 Miliar. (2015). Jawa Pos, (11 February 2015), pg. 7 
medical practice that if a primary physician (primary care physician / PCP) made a mistake then a specialist as a supervisor must account for the load losses. Therefore, accountability is called liability risk (risico aanspraklikjheid), based on the doctrine of vicarious liability. The legal basis is Article 1367 paragraph (3) BW.

\section{Controversy Doctrine of Vicarious}

Liability In The Liability Risk Of Doctors

\section{And Hospitals}

The existence of a legal fiction, action is an act of slave masters (master), then doctrine vicarious liability, let the master answer or by any other name responded superior become commonly used by the judges to liability employers over employees fault. This doctrine is also applied in the therapeutic relationship between doctor and patient to resolve malpractice case against patients on the doctor, nurse or hospital $^{23}$. Some examples of cases below indicated that the doctrine of vicarious liability used by judges in resolving the cases in question. The case of Puri Cinere Hospital (2007), the Supreme Court ruling stated that the doctor had made a mistake when performing tonsillectomy to the

\footnotetext{
${ }^{23}$ Case of Vincent McDonald vs Aliquippa Hospital (1992), in Ann Helm, Op cit, page 166. See case Ward $v$. Gordon, 999 F.2d 1399 (9th Cir 1993) and Alexander v. Mount Sinai Hospital Med. Ctr, 484 F. 3d 889 (7th Cir 2007), also Karas v. Jackson, 582 F.Supp, 43 (ED.Pa. 1983), in Marcia M. Boumil and Paula A. Hattis. (2011). Medical Liability. United State Of America: West Publishing, St Paul, , pg. 213
}

patient so that the patient's voice becomes nasal. Therefore Hospital where doctors worked stretcher sentenced to pay compensation of US \$520 million to the patient as a victim of the malpractice. Some examples of cases outside the country, among others, the case of Nelson v. Trinity Medical Center (1988) ${ }^{24}$. In other cases, Crown v. Provost $(1963)^{25}$.

Harold J. Laski criticizes this doctrine by saying that the doctrine was pleasant but did not solve the problem. This is reflected in the statement that:

"For while everyone can see that the master ought to answer for acts he has authorized, why he be liable either where no authorization can be shown, or where the express prohibition of an act exist? Latin may bring us comfort but it will not solve our problems." 26

So with the opinion of W. Page Keeton is considered that most courts only hide behind the phrase "he who acts through another person commits an own actions, such as the statement that:

"Most courts have made little or no effort to explain the result, and have taken refuge in rather empty phrases', such as' he who does a

\footnotetext{
24 Ann Helm, (2006). Malpraktik Keperawatan. Jakarta: Buku kedokteran AGC, pg. 14

${ }^{25}$ Ibid.

${ }^{26}$ Harold J. Laski, "The basic of Vicarious Liability", Yale Law Journal, December 1016, page107. Documentated in library of University of Toronto since 23 July 1924 still nowdays. In Yusuf Shopie. (2011). Tanggung Jawab Pidana Korporasi Dalam Hukum Perlindungan Konsumen di Indonesia. Bandung: Citra Aditya Bakti, pg. 374
} 
thing through another does it himself, 'or the endlessly repeated formula of' respondent superior ', the which in itself means nothing more than 'look to the man higher up." 27

Various experts like O.W. Holmes ${ }^{28}$, Frederic Cunningham ${ }^{29}$ and Gary $\mathrm{T}$ Schwartz $^{30}$, also J.W. Neyers ${ }^{31}$, not less harshness against this doctrine with a variety of reasons.

\section{Principle of Liability Risk as Proportionate \\ Reasoning Based on Juridical Considerations}

Reasoning based on juridical considerations or often called the legal reasoning included the most important part in the science of law, this concept is determining how the law is applied in legal praxis measures. The term legal reasoning in the English vocabulary is called legal reasoning meaningful legal arguments, the reasoning of the law. According to Arief B. Sidharta, legal reasoning or legal reasoning is problematic thinking activities of legal subjects (human) as individual and social

\footnotetext{
${ }^{27}$ W. Page Keeton et al in Henry Campbell. (1990). Black's Law Dictionary, minn-West Publishing co, St Paul, pg. 1338

${ }^{28}$ O.W. Holmes. "Agency" (1890-91) 4 Harv. L. Rev. 345; (1891-92) 5 Harv. L. Rev. 1 at 14

29 Frederic Cunningham. "Respondeat Superior In Admiralty" (1905-06) 19 Harv. L. Rev. 445 at 445.

${ }^{30}$ Gary T. Schwartz. "The Hidden and Fundamental Issue of Employer Vicarious Liability" (1996) 69 S. Cal. L. Rev. 1739 at 1745.

${ }^{31}$ J.W. Neyers, "A Theory Of Vicarious Liability" in www.ucc.ie/law, access on 21-10 2013.
}

beings in the circle of culture. Notwithstanding the foregoing, the legal reasoning does not find a resolution to the open spaces without limits. There is guidance for legal reasoning to also ensure the stability and predictability of its decision by referring to the system of positive law. Based on this view, citing Heide, B. Arief Sidharta call this type of argumentation in legal reasoning as "thinking of systematic problematical " (gesystematiseerd probleemdenken).

According to Johan Nasution Bahder, profession of doctor or dentist is a functional group that works on the basis professionalism but administratively they are employees of the Hospital. Them in performing their duties are paid by governments or owners of the Hospital for their professional expertise. On the basis of such a working relationship, legal action is the responsibility of the medical staff Hospital. Hospital liability against unlawful healthy acts power, as explained in the chapters before classified as liability risks. Accountability is based on the doctrine of vicarious liability based on Article 1367 paragraph (3) BW namely:

"Employers and those who raise other people to represent their affairs, is responsible of damages issued by servants or subordinates 
them in doing the work for which these people are wearing."

Some of the reasons for objection application of the vicarios liability doctrine are (1) because there are no restrictions against the law to subordinate attributable to the employer. Employer liability covers all types of unlawful acts committed by subordinates. It's just like an employee telling employers "I may make a mistake anything because you would relieve me of the damage I was doing" and ironically, the employer will say, "Yes, of course." (2) no employer agrees will it especially if it includes a fatal negligence and is not limited to things that could be borne by the employer. (3) will not spur employees to be careful in the future; (4) it would be contrary to good reception, especially when the employer has tried to provide training and skills and (5) would be illogical to set in the contract of employment for the purpose of the contract is set up a good working relationship and mutual lucrative.

Anomalies doctrine of vicarious liability in its application it can cause injustice to a specialist or hospital either as an employer or in the capacity of principal. Therefore, in order to bridge the gap liabilities then of course we need a principle of proportionate liability risks.
Proportionality means as "underlying principles underlying the exchange or the rights and obligations of the parties in proportion to their part in the whole process or contractual". The size of proportionality exchange of rights and obligations based on the values of equality (equitability), freedom-proportional distribution, of course, also can not be separated from the principle or principles of rigor (zorgvuldigheid), feasibility (redelijkheid; reasonableness) and propriety (billijkheid; equity). The principle of proportionality is not concerned about the balance (equality) results mathematically, but more emphasis on the proportion of distribution of rights and obligations between the parties are ongoing basis and appropriate (fair and reasonableness) ${ }^{32}$. The principle of proportionality or referred to by the term "equitability contract" (to borrow a phrase Peter Mahmud Marzuki) should consist of justice and fairness. Meaning of "equitability" shows a similar relationship (equality), even-handed and fair (fair), meaning that the contractual relationship basically takes place proportionally and fairly. With reference to the principle of aequitas praestasionis, namely the principle

\footnotetext{
${ }^{32}$ Agus Yudha Hernoko. (2010). Hukum Perjanjian Asas Proporsional dalam Kontrak Komersil. Jakarta: Kencana Prenada Media Group, pg. 89
} 
that requires collateral balance and the teachings justum Pretium, the appropriateness according to the law. There is no denying that the similarity of the parties never existed. Conversely, when the parties entered into the contract are in the same circumstances. But inequality should not be exploited by the dominant party to impose its will be inadequate to the other party. Under such circumstances, the principle of proportionality is meaningless equitability ${ }^{33}$

Based on the explanation above, the contract of cooperation among medical professionals legally telemedicine must meet the following elements:

a. Showed a shared commitment (as a good faith intention of the parties) are driven by a desire professional cooperation;

b. The special nature of the employment contract must contains special rules and values especially the most important is that " the specialist doctor or hospital as employer must promise to treat their employees fairly "and instead" doctor or primary nurse promised as employees to represent the interests of specialist doctors or Hospital as a

\footnotetext{
${ }^{33}$ Peter Mahmud Marzuki. (2003). "Batas-batas Kebebasan Berkontrak". Jurnal Yuridika, 18(3): 193-194. Quoted by Agus Yudha Hernoko, ibid, page 86
}

duty (duty) of the employer that must be done carefully with great caution";

c. The employer is fully aware that there are consequences as a businessman to take the risk of their advantages and disadvantages and therefore it stands in front of them. As for the staff because he is between them (gains and losses) then there is a consequence to benefit from his work, as well as a risk of loss associated with it;

d. That in order to produce beneficial cooperation, and to demonstrate the fairness of the contract, the promise of compensation must be expressly or impliedly included as an important clause in the employment contract;

e. Indemnification arrangement clause should be able to describe the characteristics of the liability risk is based on the doctrine of vicarious liability;

f. The exclusivity clause that any loss will very likely substitute if considered as limiting the ability of indemnity obligations as a whole to the situation assessed based on the status and wealth of each party and by situation (vide Article $1371 \mathrm{BW}$ ). Conversely, when justifying their 
compensation unnatural would be a burden which is not reasonable for the offender;

g. Conceptual and definitional aspects of the liability risk based upon doctrinal vicarious liability should be reduced from the essence of the principle of trust in the superiorsubordinate or agency. No comprehensive of vicarious liability if there is abuse of trust. The principle of trust is the basis of accountability that should not be abused or displaces;

h. Fundamental core of the nature and effect of a breach of contract is from the presence or absence of a desire to "take reasonable care to prevent the loss or the cause and effect."On the contrary " there is no promise to replace the losses caused deliberate neglect, haphazard or faith bad or grossly negligent causing fatal losses or because of carelessness repetitive";

i. Failing to supervise the employee is not a reason indemnity objective rationality but rather the failure is responsible for the implementation of the contract itself personally;

j. Essential conditions (strong condition) that is created from the "causes" and "condition" (cause and condition) as being proximate cause can be used to determine the risk of liability for damages. But more important are the nature of the risk and the cause of the intervention (intervening cause);

k. The court must implement the conditions for exceptions to the application of risk-based liability doctrinal vicarious liability when:

1. Because the losses are due to acts reprehensible or inconsistent with the primary purpose of the scope for cooperation

2. Where to apply it would be incompatible with rational reasons that make sense to any sensible person (reasonable man).

The principle of accountability proportionally risks are not intended to eliminate the doctrine of vicarious liability through their contractual terms. But on the contrary, should be seen as an implementation of the concept of contractual subrogation and indemnity for certain relationships between employers, employees, and victims who are disadvantaged. 
Reasoning Based On Philosophical

\section{Considerations}

Philosophical aspect is the core aspect of the truth and justice. Benjamin C. Zipursky equity theory divides into two parts, namely the theory of distributive justice and corrective justice theory. Distributive justice is basically checking static aspects of justice, especially the state, while the corrective justice examines the dynamic aspect of justice. Meanwhile, according to Julian Lamont and Christi Favour, the theory of distributive justice is essentially an understanding of justice that demands proportionality guaranteed rights of individuals or communities to appropriate proportions to each other and no one harmed $^{34}$. The theory of distributive justice outlines the normative principles designed to guide the allocation of benefits and burdens of economic activity. In other words, individuals in the community will evaluate the distribution of the results together in the community based on certain principles. If people feel there is a distribution that violates these principles then he will take action to restore the proportion of distribution to be returned in accordance with the principle. While

\footnotetext{
34 Julian Lamont and Christi Favour, Distributive Justice, The Stanford Encyclopedia of Philosopy, (full 2008 Edition) in Muhammad Yusuf. (2014). Eksistensi Kejaksaan Sebagai Pengacara, Dissertation, Malang: Brawijaya University.
}

corrective justice theory in principle is to how to restore the rights of an individual or community justice who have been harmed or disturbed by someone else, so that the individual or the community to regain their rights to justice or justice compensation for the losses they experienced. Corrective justice theory is a theory group that discussed the issues of justice that arise in modern society such as motor vehicle accidents, malpractice doctors, and so on. This theory is often called the supported theory, because of the focus on the promises of supported parties involved.

For the positivistic, justice corrective contained in Article 1367 paragraph (3) $\mathrm{BW}$, can be the basis for the judge to decide lawsuit for compensation from parties who feel aggrieved by setting to employers to account for the errors of employees despite the fact that the employer with has expressly prohibits the act concerned or though the act was outside office hours. Accountability is also not dependent on the existence of a violation of norms or fault by the employer. Anyway, as long as there is still a superior-subordinate relationship, and the fact that there are errors subordinate then the employer should be held accountable. ${ }^{35}$ This doctrine can even be extended to the

\footnotetext{
${ }^{35}$ Djasadin Saragih, Op.cit, pg. 135
} 
subordinate acts committed with all the work done in the task, regardless that the employer has detected the error or have taken steps to stop the occurrence of greater losses. 36 This regulation by Amanda Pinto and Martin Evans has actually put the employer and the company became a victim of a criminal offense committed by the employee (servant) or representative (agent). Whereas the employer or the company had clearly indicates such offenses as a prohibited act both within the company regulations and the employment agreement (contract of employment) between the employer (employer) and subordinates (employees; agent). ${ }^{37}$

Although it sounds absurd but by ideology positivist legal decisions can be deduced logically from the rules that already exist in advance without having to refer to the social objectives, virtue, and morality, however unfair and limited sound legislation which exists. The law is the law and the orders of legal certainty it can be

\footnotetext{
${ }^{36}$ The view of UK Supreme Court in case Lister vs Hesley Hall Ltd, written by Paula Giliker. (2014). Vicarious Liability in Tort: A Comparative Perspective, Cambridge Studies in International and Comparative Law (No. 69). Cambridge University Press, pg. 2-3. In www.cambridge.org, access on 23 October 2014.

37 Amanda Pinto and Martin Evans. (2003). Corporate Criminal Liability. London: Sweet \& Maxweel, pg. 20
}

enforced $^{38}$. The positivistic outlook which is opposed by the view that the principle of virtue and morality must be considered for measuring the validity of the law. Adherents of morality law principle that the law must reflect morality. Therefore, the law leaves the principles of morality, even contrary to morality, may or may not be adhered to based on a moral right (moral right). ${ }^{39}$

Justice law (legal justice) in the positivism approach is justice based on law and legislation. That means the judge in deciding cases based only on positive laws and regulations. In this justice, judge or court only as a mere law enforcement. The judge did not need to look for other sources of law outside of the written law and the judge only viewed implement laws on a concrete case mere rational, in other words, the judge as a funnel legislation.

Indonesia considers law legal system is not like that. Justice law (legal justice) should not only be based on a statute for a condition may be it will cause injustice to the community, because the statutory law that was created to have power behavior is limited where at some point the power these behaviors will die along with the occurrence of changes in the values of

\footnotetext{
38 Prija Djatmika. (2008). Problem Menegakkan Substantif. Harian Jawa Pos, Wednesday 10 December 2008, pg. 4

39 Ibid
} 
justice. Based on these circumstances, the moral justice (moral justice) and social justice (social justice) applied by the judge Indonesia with an obligation for them to explore the values that live in the community law. (Vide Article 5 (1) of Law No. 48 of 2009) as the implementation of the constitutional mandate of Article 24 paragraph 1 of the 1945 Constitution which states the judicial power is an independent power to organize judicial administration to uphold law and justice. Satjipto Rahardjo found in the law there is morality it can be seen from the principles of law which is not only a requirement of the existence of a legal system but also the classification of legal systems that contain a certain morality ${ }^{40}$. Based on the explanation above, by using the theory of corrective justice, the application of legal norms contained in Article 1367 paragraph (3) BW, (legal justice) can be ruled out if the cause of injustice. A good law is the law of life in society (the living law) as the value of justice (social justice).

Political law as reflected in the court decision today, seems to begin to experience a shift of (legal justice) Article 1367 paragraph (3) BW, moving towards (social justice). In the West itself continues to change the inevitable. Classical Western

\footnotetext{
${ }^{40}$ Satjipto Rahardjo. (1986). Ilmu Hukum. Bandung: Alumni, pg. 91-92
}

legalistic paradigm has changed in the United States since the $1950 \mathrm{~s}^{41}$. Liability risks with Vicarius liability doctrine, now began to be applied in cases of strict and limited.

\section{Reasoning Based on Sociological Considerations}

As noted Roscoe Pound, legal experts Jellinek stated, if a legal order must apply in practice, then the usefulness of social psychological must be assured. Roscoe Pound saw the phenomenon that the rules that created the court and the law, they continue to experience failure in the absence of social security of the psychological as stated Jellinek. ${ }^{42}$

A rule of law must be a law of nature that is embraced by the people. Wirjono Prodjodikoro said that if a stream can spread its wings amongst the people in the community who do not adhere to a nature of law as a rule of law, then most likely the rule of law will not be obeyed society (not effective) that is said to be a die (doode leffer). ${ }^{43}$

Criticism of the jurists above shows that the social psychological aspects

\footnotetext{
41 Achmad Ali. (2002). Keterpurukan Hukum di Indonesia (Penyebab dan Solusi). Bandung: Cipta Karya, pg. 478

${ }^{42}$ Roscoe Pound. (1965). The Task of Law, Translate by Muhammad Radjab, Jakarta: Bharata, pg. 76-77

43 R. Wirjono Prodjodikoro. (1988). Asas-Asas Hukum Perdata. Bandung: Bale Bandung, pg. 14-15
} 
determine the quality of the law, including court decisions, for the realization of the effective of law because public support. The reality shows that the world is constantly changing where the paradigm of pure legal science who rejected sociology and other disciplines increasingly irrelevant. The law is established by and for the people so that the law will not be able to stand alone without sociological factors. In the West itself is also ongoing change is inevitable, the classic western legalistic paradigm has changed in the United States since the 1950s in the judicial reform. Chief Justice Holmes, Cordozo, Llewellyn, Frank, Gray and others. a pioneer in the paradigm of social justice in the future. ${ }^{44}$

In the Netherlands that applying civil law has also left paradigm legalistic western classic since 1919 to expand the meaning of tort that is no longer based solely on the law but also as an act or omission contrary to the rights of others or in conflict with the legal obligations of the perpetrator or contrary to morality and necessity that must be respected in the social life of the people or objects as a result of actions that have caused losses in others, is obliged to pay compensation. Thus the Supreme Court of the

\footnotetext{
${ }^{44}$ Achmad Ali, Op cit,pg. 478
}

Netherlands have changed the paradigm that the law is not just what is in the statute books but also recognize "good morals" as part of the law that since 1919 there has been a paradigm shift in the country applying the civil law.

According Artidjo, the obligation of judges to explore the values of law and justice in society is a juridical obligation for judges, according to the Basic Law of Judicial Authority. If the judge simply decide the case based solely listed in the law he would be trapped in the empty container. Law without a sense of justice, such as the container is empty. Judges are supposed to examine the meta-juridical. This means that the values behind the rules of law. Moral message conveyed by the same Artidjo moral messages told by Satjipto Rahardjo, in a progressive legal theory, namely that justice can not be directly found in the formal logical process. Justice was obtained through intuition. Arena formal logical arguments "sought" after justice is found for framing a formal judicial decision which is believed to be the fair. a breakthrough that made him more priority objectives and context of texts rather than mere rules. Normative whether a rule is not valid or not is determined by the validity of the rule, but if in the summum bonum of whom 
there are common sense is accepted as something noble, good, and true and worthy, then it must be respected. Liability to pay compensation for the unlawful acts of employees who have been perceived to be fair if it is paid by the employer, it began to change because it is not always considered fair. In the practice of everyday life began many common behaviors that require employers and subordinates proportional liability in the contract (written or unwritten) in the working relationship between them.

\section{Medical Practitioner Liability} Telemedicine based Interactive Justice as the Principle of Liability Risk Proportional.

To determine liability in the form of medical practice telemedicine proportionately, it would require a theory by which to determine the extent of the liability of the telemedicine medical practitioner in the case when they are performing illegal acts that harm patients. Given as it relates to the obligation to be accountable to indemnify. Then according to the author is very relevance to the interactive theory of justice.

According Richrad Wright, that the theory of interactive justice is a theory about the legal liability (legal responsibility) for any interactive action between humans as a consequence of the law, for their mutual respect for freedom of external (right to equal external) per person. As the opinion of the author of the following quote:

"It is Generally assumed that the basic purpose of law is or should be the implementation of justice: the creation and maintenance of Reviews those conditions that are properly specifiable bay law for the flourishing and fulfillment of each person in the community as a free and equal rational being. This flourishing depends upon the promotion of each person's equal freedom, the which has an internal aspect and an external aspect. The internal aspect, the which law can not and should not attempt to control, is a matter of personal virtue-one's shopping and living one's life by Choosing and acting in accordance with the morally proper ands. The external aspect, the which is the proper concern of justice and law, is one's practical exercise of one's freedom in the external world, the which must be consistent external roommates the equal freedom of every other person. As Kant put in his supreme principle of right: [S] a act externally that the free use of your choice can coexist with the freedom of everyone in accordance with a universal law". ${ }^{45}$

Richard Wright saw that where compensation plays an important role in

\footnotetext{
${ }^{45}$ Richard W. Wright, "Grounds And Extent of Legal Responsibility", Law Review: 40 San Diego L. Rev 14252003, in Edmon Makarim. (2010). Tanggung Jawab Hukum Penyelenggara Sistem Elektronik. Jakarta: Rajawali Pers, page 189.
} 
interactive justice to protect everyone from "harmful interaction 'commonly applied in unlawful acts (tort law) and contract law and civil law in general. In essence, Richard Wright found liable in criminal and civil law is the same as the sanctions against those who commit "harmful interaction '. If the civil termed 'private wrongs' in violation of the contract and a person's property while the criminal 'public wrongs' it is for the dignity (dignity), the norms of society and public order (public peace and order $)^{46}$. Civil legal liability, if in view of the liabilities side, then any actions that occur can be known from before and after the occurrence of an event or action (accident), so that the legal responsibility can be divided into two things:

a. Responsibility before the occurrence of an event and

b. Responsibility after the occurrence of an event

Responsibility before the event (exante liability) is liable to comply with all applicable laws and / or regulations in order to provide something decent to the public (e.g. safety regulation, standardsworthy trade / standard merchantability, the standard of service / quality of service, and the application of the principles of

\footnotetext{
${ }^{46}$ Ibid.
}

good governance in the conduct of the profession something). While about legal liability after the event (ex post liability) is an obligation to restore the injured party to its original state.

The central point of accountability for risk is overcome losses by raising prudential standards, except against risks that can not be predicted.

\section{CONCLUSION}

Characteristics of telemedicine in medical practice to form the legal convergence of telematics combined with health law. This collaboration between the two disciplines makes medical practice telemedicine experience with the integration of the principles of science in information communication technology and innovative medical science. These developments are bringing changes that bring new values in the therapeutic relationship, which allows the companion of therapeutic relationship done without specialist doctors and patients. This is the consequence of the law against liability lawsuit occur when malpractice medical doctor as a result of devolution of authority and mandate under the principle of delegation.

Relationship of law in medical practice telemedicine is a working relationship that is based on a contractual relationship or 
because legislation. Delegation of the medical action can be done by specialists as the giver of power to the primary physician as the endorsee. Likewise in the context of the employment relationship between the hospital with health care workers. If the employment relationship raises losses due to errors made by the authorized person, the juridical apply the principle of liability risks (risico aanspraklijkheid) based on the doctrine of vicarious liability. The legal basis is Article 1367 paragraph (3) B.W. and Article 46 of Law No. 44 Year 2009 About Hospital. In practice it is likely to cause controversy and injustice. Thus, in its application, the judge is obliged to explore the values of justice and law in the society (vide Article 5 (1) of Law No. 48 of 2009).

The principle of liability risks in medical practice telemedicine proportionally refers to professional liability among medical practitioners telemedicine. The theoretical legitimacy is based on a professional relationship (professional relationship) in the transfer of medical action based on the code of ethics, professional standards and service standards, and standard operating procedures. So the consequences responsibilities not necessarily just based on the error primary physician (primary care physician / PCP) or primary nurse as their subordinates as intent doctrine of vicarious liability. Nomenclature "proportionate" in a significant liability risk as a distribution of rights and obligations of professionals in proportion to the fault of each party are based on the values of equality (equitability), fit and proper (fair and reasonableness). Accountability based on an equity point interactive (interactive justice) which is based on the values of professional skill, prudence or austerity, responsibility, and counterpart also the desire to do good for the sake of the patient's recovery (doing good).

\section{SUGGESTIONS}

It should be made a standardization of electronic systems technology telemedicine and medical education standards nationwide telemedicine. In addition, should be drawn up standard operating procedures, standards of practice and competence standards of health workers, including the resource capabilities of telemedicine medical practitioners in the field of forensic information technology/FIT (computer forensics).

It should be made a contract of employment in a comprehensive manner, especially governing liability risks 
proportionally as a form of governance that good medical practice telemedicine. The judge should have knowledge of medical practice in question and the sensitivity to absorb the values and sense of justice in the community in implementing paragraph of Article 1367 (3) BW and Article 46 of Law Number 44 Year 2009 about Hospital. It should be legislation policy as a form of State responsibility (legal paternalism) to organize, protect and provide the fulfillment of the rights of citizens on the legal implications from medico legal telemedicine. Regulations intended specifically to provide legal certainty on liability and legal compliance (legal compliance) practitioners telemedicine and / or Hospital as providers of electronic systems in telemedicine by adopting the principles of the application of the best (best practices and good practice) and examination of the law (legal audit), as well as the general principles of international telemedicine medical practice (general principles).

\section{BIBLIOGRAPHY}

Achmad Ali. (2002). Keterpurukan Hukum di Indonesia (Penyebab dan Solusi). Bandung: Cipta Karya.

Agus Purwadianto. "Praktisi Medis Siap Bersaing dalam Masyarakat ASEAN. Majalah Masyarakat ASEAN, Media
Publikasi Direktorat Kerja Sama ASEAN Kementerian Luar Negeri, Edisi 6, December 2014.

Agus Yudha Hernoko. (2010). Hukum Perjanjian Asas Proporsional dalam Kontrak Komersil. Jakarta: Kencana Prenada Media Group.

Amanda Pinto and Martin Evans. (2003). Corporate Criminal Liability. London: Sweet \& Maxweel.

Ann Helm, (2006). Malpraktik Keperawatan. Jakarta: Buku kedokteran AGC.

Craig J, Patterson V. (2005). "Introduction to the Practice of Telemedicine". Journal Telemedicine and Telecare, 11(1): 3 - 9 .

Danrivanto Budhijanto. (2010). Hukum

Telekomunikasi Penyiaran dan Teknologi Informasi Regulasi dan Konvergen. Bandung: Refika Aditama.

Djasadin Saragih. (1985). Pokok-Pokok Hukum Perikatan. Surabaya: Airlangga University.

Elias Mossialos, Sarah Thomson and Annemarie Ter Linden. (2004). "Information Technology Law and Health Systems in the European Union," International Journal of Technology Assessment in Health Care, 20 (4): 498508.

Frederic Cunningham."Respondeat Superior In Admiralty". (1905-06) 19 Harv. L. Rev. 445 at 445

Gary T. Schwartz. (1996). "The Hidden and Fundamental Issue of Employer Vicarious Liability". 69 S. Cal. L. Rev. 1739 at 1745

Yusuf Shopie. (2011). Tanggung Jawab Pidana Korporasi Dalam Hukum Perlindungan Konsumen di Indonesia. Bandung: Citra Aditya Bakti.

Muhammad Yusuf. (2014). Eksistensi Kejaksaan Sebagai Pengacara. Dissertation. not published. Malang: Brawijaya University. 
Marcia M. Boumil and Paula A. Hattis. (2011). Medical Liability, West Publishing, St Paul United Of America,.

O.W. Holmes, "Agency" (1890-91) 4 Harv. L. Rev. 345; (1891-92) 5 Harv. L. Rev. 1 at 14

Pemerintah Provinsi Jawa Timur. Rencana Strategis (Renstra) Rumah Sakit Dr. Soetomo Tahun 2009-2014.

Peter Mahmud Marzuki. (2003). Batasbatas Kebebasan Berkontrak. Jurnal Yuridika, 18(3): 193-194.

Peter Mahmud Marzuki. (2010). Penelitian Hukum, Edisi 6. Jakarta: Kencana Pernadia Media Grup.

Peter van Bossche dkk. (2010). Pengantar Hukum WTO (Word Trade Organization). Jakarta: Yayasan Obor Indonesia.

R. K. Gorea. (2005). "Legal Aspects of Telemedicine: Telemedical Jurisprudence". Journal of Punjab Academy of Forensic Medicine \& Toxicology, 5: 3

R. Wirjono Prodjodikoro. (1988). AsasAsas Hukum Perdata. Bandung: Bale Bandung.

Edmon Makarim, (2010). Tanggung Jawab Hukum Penyelenggara Sistem Elektronik. Jakarta: Rajawali Pers.

Roscoe Pound. (1965). The Task of Law, Translate by Muhammad Radjab, Jakarta: Bharata.

Satjipto Rahardjo. (1986). Ilmu Hukum. Bandung: Alumni.

Satjipto Rahardjo. (1997). Pembangunan Hukum Indonesia dalam Konteks Situasi Global, Jurnal Perspektif, 2 (2): 2

Terry Hutchinson, (2002). Researching and Writing in Law. Sydney: Law book. Co. Pyrmont-NSW.

Henry Campbell. (1990). Black's Law Dictionary. Minnesotta: West Publishing co, St Paul.

\section{Website:}

Paula Giliker, Vicarious Liability in Tort: A Comparative Perspective, Cambridge Studies in International and Comparative Law (No. 69), Cambridge University Press, see www.cambridge.org. Access on 23 October 2014.

Telemedicine and e-Health Development, in www.telemed.org.ua. access on 23 August 2013

Telemedicine apakah dapat diterapkan di Indonesia, be in http://khalidmustafa.info. Access on 12 February 2011

J.W. Neyers, "A Theory Of Vicarious Liability" in www.ucc.ie/law. Access on 21-10 2013

David Storey D. The Closer View About Law Issues In Telemedicine. http://www.hhnmag.com/hhnmag/jsp/articl edisplay.jsp? dcrpath $=$ HHNMO. Access on 12 July 2012

\section{Newspaper :}

Arief B. Witarto. (2005). Kebebasan dan Etika Ilmu Pengetahuan. Harian Bisnis Indonesia. (21 Oktober 2005).

Bayi Tertukar Ganti Rugi Rp 27 Miliar. (2015). Harian Jawa Pos, (11 February 2015).

Prija Djatmika. (2008). Problem Menegakkan Substantif. Harian Jawa Pos, (10 December 2008). 